\title{
PERKEMBANGAN MASYARAKAT DALAM DIMENSI PENDIDIKAN BERBASIS MULTIKULTURAL
}

\author{
Sampara Palili \\ Sekolah Tinggi Ilmu Tarbiyah Sunan Giri Bima, Indonesia \\ E-mail: syampara2511@gmail.com
}

\begin{abstract}
Abstrak: Artikel ini bertujuan mendeskripsikan dan menginterpretasikan tentang urgensi pendidikan berbasis multikulturalisme, dimensi pendidikan multikultural dan tujuan pendidikan multikultural yang ada di Indonesia. Metode penelitian yang digunakan adalah studi kualitatif dengan desain library research atau studi pustaka. Analisis yang digunakan adalah content analysis (analisis isi). Hasil penelitian mengungkapkan bahwa, Pendidikan multikultural sangat dirasakan penting untuk menjaga integritas bangsa Indonesia dari perpecahan horizontal sebagaimana terjadi tidak hanya sekali sepanjang Indonesia merdeka. Dengan semboyan Bhinneka Tunggal Ika, pemahaman akan pentingnya perbedaan sebagai sebuah anugerah merupakan titik tolak pendidikan berbasis multikultural. Setidaknya, ada lima dimensi pendidikan multikultural yang diperkirakan dapat membantu guru dalam mengimplementasikan beberapa program yang mampu merespon terhadap perbedaan pelajar, yaitu: pertama, dimensi integrasi isi atau materi (content integration). Kedua, dimensi konstruksi pengetahuan (knowledge construction). Ketiga, dimensi pengurangan prasangka (prejudice ruduction). Keempat, dimensi pendidikan yang sama (equitable paedagogy), dan kelima, dimensi pemberdayaan budaya sekolah dan struktur sosial (empowering school culture and social structure).
\end{abstract}

Kata kunci: Masyarakat Multikultural, Dimensi Pendidikan

\section{Pendahuluan}

Telah diketahui bersama bahwa pendidikan lahir seiring dengan keberadaan manusia, bahkan dalam proses pembentukan masyarakat pendidikan ikut andil dalam menyumbangkan proses-proses perwujudan pilar-pilar penyangga masyarakat. 
Melalui pewarisan kebudayaan dan internalisasi pada setiap individu, pendidikan hadir dalam bentuk sosialisasi kebudayaan, berinteraksi dengan nilai-nilai masyarakat setempat dan memelihara hubungan timbal balik yang menentukan proses-proses perubahan tatanan sosio-kultur masyarakat dalam rangka mengembangkan kemajuan peradabannya. Dilihat dari realitas yang ada, tidak ada masyarakat yang tidak memiliki budaya. Seorang anak yang terlahir, kemudian dia mendapatkan perawatan dan kehidupan yang baik dari keluarganya, saat itu ia menerima pendidikan yang pertama. ${ }^{1}$

Permasalahan yang dihadapi dunia pendidikan Indonesia saat ini adalah sekolah di Indonesia menjadi semakin tercabik-cabik atau terpisahkan karena alasan politis dan sosial. Berkaitan dengan alasan politis, pendidikan Indonesia saat ini merupakan hasil dari kebijakan politik pemerintah mulai dari orde lama, orde Baru, sampai orde reformasi. Misalnya, tentang ujian nasional. Hasil dari ujian nasional menentukan kelulusan murid, meskipun tidak $100 \%$ diambil dari hasil ujian nasional. Bahkan kemungkinan hasil ujian nasional menentukan untuk masuk perguruan tinggi. Sementara kita melihat terjadi ketidakadilan dibidang pendidikan atau ketidakmerataan antara pendidikan dipusat (baca: Jawa) dan daerah-daerah (baca: luar Jawa). Di samping itu, masalah kurikulum pendidikan yang sepertinya diarahkan untuk menyiapkan peserta didik menghadapi ujian nasional. Sementara itu, menurut Ainurrofiq Dawam, pendidikan juga diarahkan kepada kurikulum yang memberikan bekal kepada peserta didik untuk mampu mendapatkan pekerjaan yang menghasilkan

\footnotetext{
${ }^{1}$ H. A. R. Tilaar, Pedagogik Teoritis untuk. Indonesia (Jakarta: Kompas, 2015), 48. Lihat juga dalam Ravik Karsidi, M.S, Sosiologi Pendidikan, Cet.II (Surakarta: LPP UNS dan UNS Press, 2008), 19.

200 | Tarbiyatuna: Jurnal Pendidikan Islam; Volume 11, Nomor 2, Agustus 2018 p-ISSN: 2085-6539; e-ISSN: 2242-4579
} 
pendapatan yang besar. ${ }^{2}$ Niscaya hal tersebut semakin membebani murid dan guru. Oleh karena itu, tidak jarang sekolah melakukan diskriminasi terhadap muridnya sendiri melalui diadakannya kelas unggulan atau yang pintar disatukan dengan yang pintar dan yang tidak pintar disendirikan. Padahal hakikat pendidikan, menurut John Dewey di dalam bukunya Experience and education, adalah a social process. Education is growth. Education is not preparation for life, education is life it self. Pendidikan adalah proses sosial. Pendidikan senantiasa bertumbuh. Pendidikan bukan persiapan untuk hidup, melainkan hidup itu sendiri. Dari segi alasan sosial, pendidikan kita dicengkeram oleh globalisasi. Dalam realitas pendidikan Indonesia kontemporer, pengaruh globalisasi membangun peran ambivalen terhadap hakikat otentik pendidikan. Orientasi pendidikan dikacaukan oleh prioritas melayani persaingan global ketimbang memelihara harmoni lokal. Globalisasi dinilai telah berhasil mendekontekstualisasi arah pendidikan menuju visi kapitalisme. Pendidikan berorientasi pasar, berlogika kuantitas, hingga upaya privatisasi pendidikan adalah beberapa contoh dari fenomena ketertundukan hakikat pendidikan terhadap hasrat kapitalisme global. ${ }^{3}$ Keadaan ini jelas menutup kemungkinan bagi masyarakat kelas bawah untuk dapat menikmati pendidikan yang layak, yang adalah hak asasi setiap warga negara. Situasi sosial sudah mengkotak-kotakkan orang ke dalam kelas-kelas, menjadi tepisah-pisah. Situasi ini juga berdampak bagi wajah pendidikan kita.

\footnotetext{
2 Dapat dilihat pada laman http://www.ditpertais.net/swara/warta17-01.asp, diakses pada selasa, 24 Juli 2018

3 Tim Kreatif LKM UNJ, Restorasi Pendidikan Indonesia: Menuju Masyarakat Terdidik. Berbasis Budaya (Yogyakarta: ArRuzz Media, 2010)
} 
Bagaimana implikasi dari fenomena-fenomena tersebut bagi pembangunan bangsa dan karakter peserta didik? Fenomena tersebut di atas sangat berimplikasi bagi pembangunan bangsa dan karakter peserta didik. Suatu bangsa yang besar sudah pasti ditopang oleh sistem pendidikan yang bagus dan kontekstual. Pendidikan merupakan kereta yang dapat menjadikan suatu bangsa memiliki karakter dan peradaban. Oleh karena itu, sudah barang tentu situasi lembaga pendidikan "sekolah" Indonesia yang seperti dijelaskan di atas tadi, kalau tidak dibenahi, akan berimbas pada pembangunan bangsa dan karakter peserta didik. Karena situasi tersebut di atas justru akan membunuh karakter peserta didik, yang berimplikasi langsung pada dekonstruksi karakter dan peradaban suatu bangsa. Anak-anak dipisahkan dari sesamanya karena hal-hal tertentu. Hal tersebut dapat membuat anak-anak sulit menerima perbedaan dan bahkan cenderung egois dan primordialis.

Melihat fenomena tersebut, pendidikan di Indonesia haruslah peka meghadapi arus perputaran globalisasi. Pola pemaksaan kehendak dari pemerintah untuk membentuk satu kehidupan berbangsa yang seragam melalui aturan-aturan dalam segala aspek kehidupan harus ditinjau ulang dan dipertanyakan. Selain itu, juga gelombang demokrasi yang terjadi di negara ini menuntut pengakuan perbedaan dalam tubuh bangsa Indonesia yang majemuk. Oleh karena itu, pendidikan multikulural adalah jawaban atas beberapa permasalahan seperti telah disebutkan di atas. Perlu disadari bahwa proses pendidikan adalah proses pembudayaan dan citacita persatuan bangsa merupakan unsur budaya nasional. 


\section{Pendidikan Sebagai Agent of Change}

Perkembangan masyarakat yang sangat dinamis serta masalah-masalah sosial yang dewasa ini terus berkembang membutuhkan perhatian dan kepekaan dari seluruh elemen bangsa tidak hanya dari para pakar dan pemerhati masalah sosial namun juga dunia pendidikan yang punya peran sangat strategis sebagai wahana dan "agent of change" bagi masyarakat. Kondisi masyarakat Indonesia yang sangat plural tersebut telah memberikan kontribusi yang luar biasa terhadap perkembangan dan dinamika dalam masyarakat. Untuk itu, dipandang penting memberikan porsi pendidikan multikultural dalam sistem pendidikan di Indonesia baik melalui substansi maupun model pembelajaran. Hal ini dipandang penting untuk memberikan pembekalan dan membantu perkembangan wawasan pemikiran dan kepribadian serta melatih kepekaan peserta didik dalam menghadapi gejala-gejala dan masalah-masalah sosial yang terjadi pada lingkungan masyarakatnya. Oleh karena itu, diperlukan langkah-langkah preventif untuk mencegah berkembangnya masalah tersebut, yaitu dengan membangun pemahaman budaya yang lebih inklusif-pluralis, multikultural, humanis, dialogis-persuasif, kontekstual melalui pendidikan, media massa, dan interaksi sosial. Hal itu bisa ditempuh melalui pendidikan berbasis multikulturalisme.

Pendidikan multikultural dalam ensiklopediilmu-ilmu sosial dimulai sebagai gerakan reformasi pendidikan di Amerika Serikat selama perjuangan hak-hak kaum sipil Amerika keturunan Afrika pada tahun 1960-an dan 1970-an. Perubahan kemasyarakatan yang mendasar seperti integrasi sekolah-sekolah negeri dan 
peningkatan populasi imigran telah memberikan dampak yang besar atas lembagalembaga pendidikan. Pada saat para pendidik berjuang untuk menjelaskan tingkat kegagalan dan putus sekolah murid-murid dari etnis marginal, beberapa orang berpendapat bahwa murid-murid tersebut tidak memiliki pengetahuan budaya yang memadai untuk mencapai keberhasilan akademik. ${ }^{4}$

Banks telah mendiskripsikan evolusi pendidikan multi budaya dalam empat fase. Yang pertama, ada upaya untuk mempersatukan kajian-kajian etnis pada setiap kurikulum. Kedua, hal ini diikuti oleh pendidikan multietnis sebagai usaha untuk menerapkan persamaan pendidikan melalui reformasi keseluruhan sistem pendidikan. Ketiga, kelompok-kelompok marginal yang lain, seperti perempuan, orang cacat, homo dan lesbian, mulai menuntut perubahan-perubahan mendasar dalam lembaga pendidikan. Keempat, perkembangan teori, riset dan praktek, perhatian pada hubungan antar-ras, kelamin, dan kelas telah menghasilkan tujuan bersama bagi kebanyakan ahli teoritisi, jika bukan para praktisi, dari pendidikan multibudaya. Gerakan reformasi mengupayakan transformasi proses pendidikan dan lembagalembaga pendidikan pada semua tingkatan sehingga semua murid, apapun ras atau etnis, kecacatan, jenis kelamin, kelas sosial dan orientasi seksualnya akan menikmati kesempatan yang sama untuk menikmati pendidikan. ${ }^{5}$

\footnotetext{
${ }^{4}$ Kuper, Adam \& Jessica Kuper, Ensiklopedi Imu-Imu Sosial (Jakarta: PT Raja Grafindo Persada 2000), 20

${ }^{5}$ Banks, J.A. "Multicultural Educatian: Historical Development, Dimentions and Practrice" In Review of Research in Education, vol. 19, 1993. Edited by L. Darling- Hammond. Washington, D.C.: American Educational Research Association.
}

204 | Tarbiyatuna: Jurnal Pendidikan Islam; Volume 11, Nomor 2, Agustus 2018 p-ISSN: 2085-6539; e-ISSN: 2242-4579 
Joyce menyebutkan bahwa pendidikan multibudaya bertujuan untuk sebuah pendidikan yang bersifat anti rasis; yang memperhatikan keterampilan-keterampilan dan pengetahuan dasar bagi warga dunia; yang penting bagi semua murid; yang menembus seluruh aspek sistem pendidikan; mengembangkan sikap, pengetahuan, dan keterampilan yang memungkinkan murid bekerja bagi keadilan sosial; yang merupakan proses dimana pengajar dan murid bersama-sama mempelajari pentingnya variabel budaya bagi keberhasilan akademik; dan menerapkan ilmu pendidikan yang kritis yang memberi perhatian pada bangun pengetahuan sosial dan membantu murid untuk mengembangkan ketrampilan dalam membuat keputusan dan tindakan sosial. ${ }^{6}$

Wacana multikulturalisme untuk konteks di Indonesia menemukan momentumnya ketika sistem nasional yang otoriter-militeristik tumbang seiring dengan jatuhnya rezim Soeharto. Saat itu, keadaan negara menjadi kacau balau dengan berbagai konflik antarsuku bangsa dan antar golongan, yang menimbulkan keterkejutan dan kengerian para anggota masyarakat. Kondisi yang demikian membuat berbagai pihak semakin mempertanyakan kembali sistem nasional seperti apa yang cocok bagi Indonesia yang sedang berubah, serta sistem apa yang bisa membuat masyarakat Indonesia bisa hidup damai dengan meminimalisir potensi konflik.

Menurut Sosiolog Universitas Indonesia, Parsudi Suparlan, multikulturalisme adalah konsep yang mampu menjawab tantangan perubahan zaman dengan alasan multikulturalisme merupakan sebuah ideologi yang mengagungkan perbedaaan

\footnotetext{
${ }^{6}$ Joyce, Bruce, et. al. Model of Teaching-edisi kedelapan, terj. Achmad Fawaizd (Yogyakarta: Pustaka Pelajar, 2009).

Tarbiyatuna: Jurnal Pendidikan Islam; Volume 11, Nomor 2, Agustus 2018 | 205 p-ISSN: 2085-6539; e-ISSN: 2242-4579
} 
budaya, atau sebuah keyakinan yang mengakui dan mendorong terwujudnya pluralisme budaya sebagai corak kehidupan masyarakat. Multikulturalisme akan menjadi pengikat dan jembatan yang mengakomodasi perbedaan-perbedaan termasuk perbedaan kesukubangsaan dan suku bangsa dalam masyarakat yang multikultural. Perbedaan itu dapat terwadahi di tempat-tempat umum, tempat kerja dan pasar, dan sistem nasional dalam hal kesetaraan derajat secara politik, hukum, ekonomi, dan sosial.

\section{Pendidikan Multikultural}

Apakah pendidikan multikultural itu? Pendidikan multikultural dapat dirumuskan sebagai wujud kesadaran tentang keanekaragaman kultural, hak-hak asasi manusia serta pengurangan atau penghapusan berbagai jenis prasangka (prejudice) untuk membangun suatu kehidupan masyarakat yang adil dan maju. ${ }^{7}$

Multikultural berasal dari dua kata yaitu multi dan kultur, multi artinya banyak dan kultur artinya budaya. Lebih jelasnya makna pendidikan multikultural dapat dipahami secara mendalam melalu perumusan arti dari beberapa ahli:

1. Gibson mendefinisikan bahwa pendidikan multikultural adalah suatu proses pendidikan yang membantu individu mengembangkan cara menerima, mengevaluasi, dan masuk ke dalam sistem budaya yang berbeda dari yang mereka miliki. ${ }^{8}$

\footnotetext{
${ }^{7}$ Syafiq A. Mughni, Hasan Bandung: Pemikir Islam Radikal (Surabaya: PT Bina Ilmu, 1994), 104.

8 Gibson, Ivancevich. Organisasi dan Manajemen Perilaku Struktur Proses (Jakarta: Penerbit Erlangga. 1984)

206 | Tarbiyatuna: Jurnal Pendidikan Islam; Volume 11, Nomor 2, Agustus 2018 p-ISSN: 2085-6539; e-ISSN: 2242-4579
} 
2. Nieto menyebutkan bahwa pendidikan multibudaya adalah pendidikan yang bersifat anti rasis, yang memperhatikan ketrampilan-ketrampilan dan pengetahuan dasar bagi warga dunia, yang penting bagi semua murid, yang menembus seluruh aspek sistem pendidikan, mengembangkan sikap, pengetahuan dan ketrampilan yang memungkinkan murid bekerja bagi keadilan social, yang merupakan proses dimana pengajar dan murid bersama-sama mempelajari pentingnya variabel budaya bagi keberhasilan akademik dan menerapkan ilmu pendidikan yang kritis yang memberi perhatian pada bangun pengetahuan sosial dan membantu murid untuk mengembangkan ketrampilan dalam membuat keputusan dan tindakan sosial. $^{9}$

3. Prudence Crandallmengemukakan bahwa pendidikan multikultural adalah pendidikan yang memperhatikan secara sungguh-sungguh terhadap latar belakang peserta didik baik dari aspek keragaman suku (etnis), ras, agama (aliran kepercayaan) dan budaya (kultur). Secara lebih singkat Andersen dan Custer (1994) mengatakan bahwa pendidikan multikultural adalah pedidikan mengenai keragaman budaya.

4. Menurut James. A. Banks, pendidikan multikultural adalah konsep atau ide sebagai rangkaian kepercayaan dan penjelasan yang mengakui dan menilai pentingnya keragaman budaya dan etnis dalam membentuk gaya hidup pengalaman sosial

\footnotetext{
${ }_{9}^{9}$ Nieto, S. Affirming Diversity: The Sociopolitical Context of Multicultural Education (New York: Longman. 1992)
} 
identitas pribadi dan kesempatan-kesempatan pendidikan dari individu, kelompok maupun negara. ${ }^{10}$

5. Azyumardi Azra mendefinisikan pendidikan multikultural sebagai pendidikan keragaman kebudayaan dalam merespon perubahan demografi dan kultur lingkungan masyarakat tertentu atau bahkan secara keseluruhan. ${ }^{11}$ Sedangkan Musa Asy'ari menyatakan bahwa pendidikan multikultural adalah proses penanaman cara hidup menghormati, tulus, dan toleran terhadap keanekaragaman budaya yang hidup di tengah-tengah masyarakat plural. ${ }^{12}$

Pendidikan adalah usaha sadar dan terencana untuk mewujudkan dan mengembangkan potensi dirinya untuk memiliki kekuatan spiritual keagamaan, pengendalian diri, kepribadian, akhlak mulia dan keterampilan yang diperlukan dirinya, masyarakat, bangsa dan Negara. Multikultural adalah berbagai macam status sosial budaya meliputi latar belakang, tempat, agama, ras, suku dan sebagainya.

Jadi, pendidikan multikultural adalah usaha sadar untuk mengembangkan kepribadian didalam dan diluar sekolah yang mempelajari tentang berbagai macam status sosial, ras, suku, agama agar tercipta kepribadian yang cerdas dalam menghadapi masalah-masalah keberagaman budaya.

\footnotetext{
${ }_{10}$ James Banks. Multicultural Education: Historical Development, Dimension, and Practice (USA: Review of Research in Education 1993)

11 Azyumardi Azra, Pendidikan Islam: Tradisi dan Modernisasi Menuju Milenium Baru(Jakarta: Logos Wacana Ilmu, 2000), 87.

${ }^{12}$ Musa Asy'ari, Pendidikan Multicultural dan Konflik. Bangsa, Yogyakarta: http: //kompas.com/ kompas-cetak/ 0409/ 03/ opini/ 1246546). 2004
}

208 | Tarbiyatuna: Jurnal Pendidikan Islam; Volume 11, Nomor 2, Agustus 2018 p-ISSN: 2085-6539; e-ISSN: 2242-4579 
Dari pengertian-pengertian di atas, dapat disimpulkan bahwa pendidikan multikultural merupakan respons terhadap perkembangan keragaman populasi sekolah, sebagaimana tuntututan persamaan hak bagi setiap kelompok. Pendidikan multikultural itu mencakup seluruh murid tanpa membeda-bedakan dan mendiskreditkan mereka berdasarkan gender, etnis, ras, budaya, strata sosial, agama, bakat dan kemampuan, dan lain-lain. Oleh karena itu, dengan melihat konteks Indonesia, sudah seharusnya pendidikan multikultural ini diterapkan sebagai suatu model pendidikan yang menjawab kebutuhan-kebutuhan sekolah berkaitan dengan kemajemukan dan permasalahan-permasalahan yang ditimbulkannya.

Bagaimana menerapkan pendidikan multikultural ini kedalam kurikulum pendidikan di sekolah? Untuk membentuk warga negara yang berpendidikan multikultural tidaklah mudah, banyak tahap dan prosedur yang harus dilaksanakan dalam membentuk masyarakat yang berpendidikan multikultural Indonesia, antara lain:

1. Menyiapkan materi atau kurikulum pelajaran yang mengagungkan perbedaan budaya.

2. Menyiapkan kurikulum yang mempelajari tentang budaya suku lain mulai dari tari tradisional, sastra, hasil kerajinan suku lain di Indonesia dan lain-lain.

3. Menyiapkan kurikulum yang tidak diskriminatif dengan menjunjung tinggi HAM, nilai keagamaan, nilai kultural dan kemajemukan bangsa.

4. Menyiapkan materi yang berasaskan nilai moral untuk menanamkan sikap menghargai orang, budaya, agama dan keyakinan lain. 
5. Membangun monumen maupun museum disetiap daerah untuk dijadikan penelitian budaya daerah tersebut dan dapat dijadikan tambahan bahan acuan materi pelajaran.

6. Membuka lapangan kerja seluas-luasnya untuk memproduksi hasil kerajinan tangan yang menjadi ciri khas budaya daerah.

7. Pemerataan pendidikan multikultural untuk sekolah baik dari lembaga pendidikan pemerintah maupun swasta bahkan untuk sekolah-sekolah internasional yang mempunyai kurikulum sendiri yang mengacu pada kurikulum negara lain. Pemerataan pendidikan multikultural bagi seluruh lapisan masyarakat tanpa melihat status sosialnya.

8. Mengembangkan potensi peserta didik untuk mengembangkan ketrampilan dan pengetahuan sosial budaya dengan kemajuan IPTEK.

9. Mempercepat proses hak paten semua hasil kebudayaan agar tidak diklain negara lain dan sebagainya.

10. Pendidikan multikultural harus menawarkan beragam kurikulum yang merepresentasikan pandangan dan perspektif banyak orang.

11. Pendidikan multikultural harus didasarkan pada asumsi bahwa tidak ada penafsiran tunggal terhadap kebenaran sejarah.

12. Kurikulum dicapai sesuai dengan penekanan analisis komparatif dengan sudut pandang kebudayaan yang berbeda-beda.

13. Pendidikan multikultural harus mendukung prinsip-prinisip pokok dalam memberantas pandangan klise tentang ras, budaya dan agama. 
14. Pendidikan multikultural mencerminkan keseimbangan antara pemahaman persamaan dan perbedaan budaya mendorong individu untuk mempertahankan dan memperluas wawasan budaya dan kebudayaan mereka sendiri. ${ }^{13}$

Melihat paparan diatas, pendidikan multikultural nampaknya sudah mulai dikembangkan dibeberapa sekolah di indonesia. Namun masih dibutuhkan penelitian secara mendalam untuk memperjelas konsep, metode, strategi, model, implementasi, penerapan, internalisasi, dan lainnya sehingga ditemukannya kurikulum atau konsep pendidikan multikultural yang dapat diterapkan disemua lembaga sekolah yang ada di Indonesia.

\section{Urgensi Pendidikan Berbasis Multikulturalisme}

Berdasarkan uraian di atas dapat dikemukakan bahwa paradigma pendidikan multikulturalisme sangat bermanfaat untuk membangun kohesifitas, soliditas dan intimitas di antara keragamannya etnik, ras, agama, dan budaya. Kita perlu memberi dorongan dan spirit bagi peserta didik untuk menghargai orang, budaya, agama, dan keyakinan lain. Harapannya, dengan implementasi pendidikan yang berwawasan multikultural, akan membantu siswa mengerti, menerima dan menghargai orang lain yang berbeda suku, budaya dan nilai kepribadian. Lewat penanaman semangat multikulturalisme di sekolah-sekolah, akan menjadi medium pelatihan dan penyadaran bagi generasi muda untuk menerima perbedaan budaya, agama, ras, etnis

\footnotetext{
13 Dapat diakses https://sociologypolitik...com/2015/05/makalah-pendidikan-multikultural. html di akses pada selasa, 24 juli 2018
} 
dan kebutuhan di antara sesama dan mau hidup bersama secara damai. Agar proses ini berjalan sesuai harapan, pendidikan multikultural perlu disosialisasikan dan didiseminasikan melalui lembaga pendidikan, serta, jika mungkin, ditetapkan sebagai bagian dari kurikulum pendidikan di berbagai jenjang baik di lembaga pendidikan pemerintah maupun swasta. Apalagi, paradigma multikultural secara implisit juga menjadi salah satu concern dari Pasal 4 UU N0. 20 Tahun 2003 Sistem Pendidikan Nasional. Dalam pasal itu dijelaskan, bahwa pendidikan diselenggarakan secara demokratis, tidak diskriminatif dengan menjunjung tinggi HAM, nilai keagamaan, nilai kultural dan kemajemukan bangsa. ${ }^{14}$

Bagaimana membangun pemahaman keberagamaan siswa yang inklusif di sekolah? Dalam hal ini, guru mempunyai posisi penting dalam mengimplementasikan nilai-nilai keberagamaan inklusif di sekolah. Adapun peran guru di sini, meliputi:

1. seorang guru/dosen harus mampu bersikap demokratis, baik dalam sikap maupun perkataannya tidak diskriminatif.

2. guru/dosen seharusnya mempunyai kepedulian yang tinggi terhadap kejadiankejadian tertentu yang ada hubungannya dengan agama. Misalnya, ketika terjadi bom Bali tahun 2003, maka seorang guru yang berwawasan multikultural harus mampu menjelaskan keprihatinannya terhadap peristiwa tersebut.

3. guru/dosen seharusnya menjelaskan bahwa inti dari ajaran agama adalah menciptakan kedamaian dan kesejahteraan bagi seluruh ummat manusia,

\footnotetext{
${ }_{14}$ Depdiknas, Undang-undang RI No. 20 tahun 2003.Tentang Sistem Pendidikan Nasional. pasal 04: 2003.

212 | Tarbiyatuna: Jurnal Pendidikan Islam; Volume 11, Nomor 2, Agustus 2018 p-ISSN: 2085-6539; e-ISSN: 2242-4579
} 
makapemboman, invasi militer, dan segala bentuk kekerasan adalah sesuatu yang dilarang oleh agama.

4. guru/dosen mampu memberikan pemahaman tentang pentingnya dialog dan musyawarah dalam menyelesaikan berbagai permasalahan yang berkaitan dengan keragaman budaya, etnis, dan agama.

Pendidikan multikultural sebagai sebuah konsep atau pemikiran muncul karena adanya interes politik, sosial, ekonomi dan intelektual. Wacana pendidikan multikultural pada awalnya sangat bias Amerika karena punya akar sejarah dengan gerakan hak asasi manusia (HAM) dari berbagai kelompok yang tertindas di negeri tersebut. Banyak lacakan sejarah atau asal-usul pendidikan multikultural yang merujuk pada gerakan sosial Orang Amerika keturunan Afrika dan kelompok kulit berwarna lain yang mengalami praktik diskrinunasi di lembaga-lembaga publik pada masa perjuangan hak asasi pada tahun 1960-an. Di antara lembaga yang secara khusus disorot karena bermusuhan dengan ide persamaan ras pada saat itu adalah lembaga pendidikan. Pada akhir 1960-an dan awal 1970-an, suara-suara yang menuntut lembaga-lembaga pendidikan agar konsisten dalam menerima dan menghargai perbedaan semakin kencang, yang dikumandangkan oleh para aktivis, para tokoh dan orang tua. Mereka menuntut adanya persamaan kesempatan di bidang pekerjaan dan pendidikan. Momentum inilah yang dianggap sebagai awal mula dari konseptualisasi pendidikan multikultural.

Tahun 1980-an agaknya yang dianggap sebagai kemunculan lembaga sekolah yang berlandaskan pendidikan multikultural yang didirikan oleh para peneliti dan 
aktivis pendidikan progresif. James Bank adalah salah seorang pioner dari pendidikan multikultural. Dia yang membumikan konsep pendidikan multikultural menjadi ide persamaan pendidikan. Pada pertengahan dan akhir 1980-an, muncul kelompok sarjana, di antaranya Carl Grant, Christine Sleeter, Geneva Gay dan Sonia Nieto yang memberikan wawasan lebih luas soal pendidikan multikultural, memperdalam kerangka kerja yang membumikan ide persamaan pendidikan dan menghubungkannya dengan transformasi dan perubahan sosial. Didorong oleh tuntutan warga Amerika keturunan Afrika, Latin/Hispanic, warga pribumi dan kelompok marjinal lain terhadap persamaan kesempatan pendidikan serta didorong oleh usaha komunitas pendidikan profesional untuk memberikan solusi terhadap masalah pertentangan ras dan rendahnya prestasi kaum minoritas di sekolah menjadikan pendidikan multikultural sebagai slogan yang sangat populer pada tahun 1990-an. Selama dua dekade konsep pendidikan multikultural menjadi slogan yang sangat populer di sekolah-sekolah AS. Secara umum, konsep ini diterima sebagai strategi penting dalam mengembangkan toleransi dan sensitifitas terhadap sejarah dan budaya dari kelompok etnis yang beraneka macam di negara ini.Ide pendidikan multikulturalisme akhirnya menjadi komitmen global sebagaimana direkomendasi UNESCO pada bulan Oktober 1994 di Jenewa.Rekomendasi itu di antaranya memuat tiga pesan. Pertama, pendidikan hendaknya mengembangkan kemampuan untuk mengakui dan menerima nilai-nilai yang ada dalam kebhinnekaan pribadi, jenis kelamin, masyarakat dan budaya serta mengembangkan kemampuan untuk berkomunikasi, berbagi dan bekerja sama dengan yang lain. Kedua, pendidikan 
hendaknya meneguhkan jati diri dan mendorong konvergensi gagasan dan penyelesaian-penyelesaian yang memperkokoh perdamaian, persaudaraan dan solidaritas antara pribadi dan masyarakat. Ketiga, pendidikan hendaknya meningkatkan kemampuan menyelesaikan konflik secara damai dan tanpa kekerasan. Karena itu, pendidikan hendaknya juga meningkatkan pengembangan kedamaian dalam diri diri pikiran peserta didik sehingga dengan demikian mereka mampu membangun secara lebih kokoh kualitas toleransi, kesabaran, kemauan untuk berbagi dan memelihara. Konsep pendidikan multikultural dalam perjalanannya menyebar luas ke kawasan di luar AS, khususnya di negara-negara yang memiliki keragaman etnis, ras, agama dan budaya seperti Indonesia. Sekarang ini, pendidikan multikultural secara umum mencakup ide pluralisme budaya. Tema umum yang dibahas meliputi pemahaman budaya, penghargaan budaya dari kelompok yang beragam dan persiapan untuk hidup dalam masyarakat pluralistik.Pada konteks Indonesia, perbincangan tentang konsep pendidikan multikultural semakin memperoleh momentum pasca runtuhnya rezim otoriter-militeristik Orde Baru karena hempasan badai reformasi. Era reformasi ternyata tidak hanya membawa berkah bagi bangsa kita, namun juga memberi peluang meningkatnya kecenderungan primordialisme. Untuk itu, dirasakan perlu menerapkan paradigma pendidikan multikultur untuk menangkal semangat primordialisme tersebut. Secara generik, pendidikan multikultural memang sebuah konsep yang dibuat dengan tujuan untuk menciptakan persamaan peluang pendidikan bagi semua siswa yang berbeda-beda ras, etnis, kelas sosial dan kelompok budaya. Salah satu tujuan penting dari konsep pendidikan multikultural adalah untuk 
membantu semua siswa agar memperoleh pengetahuan, sikap dan keterampilan yang diperlukan dalam menjalankan peran-peran seefektif mungkin pada masyarakat demokrasi-pluralistik serta diperlukan untuk berinteraksi, negosiasi, dan komunikasi dengan warga dari kelompok beragam agar tercipta sebuah tatanan masyarakat bermoral yang berjalan untuk kebaikan bersama. Dalam implementasinya, paradigma pendidikan multikultural dituntut untuk berpegang pada prinsip-prinsip berikut ini:

1. Pendidikan multikultural harus menawarkan beragam kurikulum yang merepresentasikan pandangan dan perspektif budaya yang ada.

2. Pendidikan multikultural harus didasarkan pada asumsi bahwa tidak ada penafsiran tunggal terhadap kebenaran budaya/sejarah.

3. Kurikulum dicapai sesuai dengan penekanan analisis komparatif dengan sudut pandang kebudayaan yang berbeda-beda.

4. Pendidikan multikultural harus mendukung prinsip-prinisip pokok dalam memberantas pandangan klise tentang ras, budaya dan agama.

5. Pendidikan multikultural mencerminkan keseimbangan antara pemahaman persamaan dan perbedaan budaya mendorong individu untuk mempertahankan dan memperluas wawasan budaya dan kebudayaan mereka sendiri. ${ }^{15}$

\footnotetext{
15 Kasinyo Harto, Model Pengembanagan Pendidikan Agama Islam Berbasis Multikultural (Jakarta: PT. Raja Grafindo Persada, 2014), 56-60.

216 | Tarbiyatuna: Jurnal Pendidikan Islam; Volume 11, Nomor 2, Agustus 2018 p-ISSN: 2085-6539; e-ISSN: 2242-4579
} 


\section{Dimensi dan pendekatan Pendidikan Multikultural}

James A. Banks mengidentifikasi ada lima dimensi pendidikan multikultural yang diperkirakan dapat membantu guru dalam mengimplementasikan beberapa program yang mampu merespon terhadap perbedaan pelajar (siswa), yaitu:

1. Dimensi integrasi isi/materi (content integration). Dimensi ini digunakan oleh guru untuk memberikan keterangan dengan 'poin kunci' pembelajaran dengan merefleksi materi yang berbeda-beda. Secara khusus, para guru menggabungkan kandungan materi pembelajaran ke dalam kurikulum dengan beberapa cara pandang yang beragam. Salah satu pendekatan umum adalah mengakui kontribusinya, yaitu guru-guru bekerja ke dalam kurikulum mereka dengan membatasi fakta tentang semangat kepahlawanan dari berbagai kelompok. Di samping itu, rancangan pembelajaran dan unit pembelajarannya tidak dirubah. Dengan beberapa pendekatan, guru menambah beberapa unit atau topik secara khusus yang berkaitan dengan materi multikultural.

2. Dimensi konstruksi pengetahuan (knowledge construction). Suatu dimensi dimana para guru membantu siswa untuk memahami beberapa perspektif dan merumuskan kesimpulan yang dipengaruhi oleh disiplin pengetahuan yang mereka miliki. Dimensi ini juga berhubungan dengan pemahaman para pelajar terhadap perubahan pengetahuan yang ada pada diri mereka sendiri;

3. Dimensi pengurangan prasangka (prejudice ruduction). Guru melakukan banyak usaha untuk membantu siswa dalam mengembangkan perilaku positif tentang perbedaan kelompok. Sebagai contoh, ketika anak-anak masuk sekolah dengan 
perilaku negatif dan memiliki kesalahpahaman terhadap ras atau etnik yang berbeda dan kelompok etnik lainnya, pendidikan dapat membantu siswa mengembangkan perilaku intergroup yang lebih positif, penyediaan kondisi yang mapan dan pasti. Dua kondisi yang dimaksud adalah bahan pembelajaran yang memiliki citra yang positif tentang perbedaan kelompok dan menggunakan bahan pembelajaran tersebut secara konsisten dan terus-menerus. Penelitian menunjukkan bahwa para pelajar yang datang ke sekolah dengan banyak stereotype, cenderung berperilaku negatif dan banyak melakukan kesalahpahaman terhadap kelompok etnik dan ras dari luar kelompoknya. Penelitian juga menunjukkan bahwa penggunaan teksbook multikultural atau bahan pengajaran lain dan strategi pembelajaran yang kooperatif dapat membantu para pelajar untuk mengembangkan perilaku dan persepsi terhadap ras yang lebih positif. Jenis strategi dan bahan dapat menghasilkan pilihan para pelajar untuk lebih bersahabat dengan ras luar, etnik dan kelompok budaya lain.

4. Dimensi pendidikan yang sama/adil (equitable paedagogy). Dimensi ini memperhatikan cara-cara dalam mengubah fasilitas pembelajaran sehingga mempermudah pencapaian hasil belajar pada sejumlah siswa dari berbagai kelompok. Strategi dan aktivitas belajar yang dapat digunakan sebagai upaya memperlakukan pendidikan secara adil, antara lain dengan bentuk kerjasama (cooperative learning), dan bukan dengan cara-cara yang kompetitif (competition learning). Dimensi ini juga menyangkut pendidikan yang dirancang untuk membentuk lingkungan sekolah, menjadi banyak jenis kelompok, termasuk 
kelompok etnik, wanita, dan para pelajar dengan kebutuhan khusus yang akan memberikan pengalaman pendidikan persamaan hak dan persamaan memperoleh kesempatan belajar.

5. Dimensi pemberdayaan budaya sekolah dan struktur sosial (empowering school culture and social structure). Dimensi ini penting dalam memperdayakan budaya siswa yang dibawa ke sekolah yang berasal dari kelompok yang berbeda. Di samping itu, dapat digunakan untuk menyusun struktur sosial (sekolah) yang memanfaatkan potensi budaya siswa yang beranekaragam sebagai karakteristik struktur sekolah setempat, misalnya berkaitan dengan praktik kelompok, iklim sosial, latihanlatihan, partisipasi ekstra kurikuler dan penghargaan staff dalam merespon berbagai perbedaan yang ada di sekolah.

J.A. Banks juga menawarkan empat pendekatan dalam pendidikan multikultural, yaitu: kontributif, adiktif, aksi sosial, dan transformatif. ${ }^{16}$

1. Pendekatan kontributif, adalah pendekatan yang dilakukan dengan cara menyeleksi buku-buku teks wajib atau anjuran dan aktifitas-aktifitas tertentu seperti hari-hari besar kenegaraan dengan hari kepahlawanan nasional. Pendekatan ini paling sedikit keterlibatannya dalam reformasi pendidikan multikultural.

2. Pendekatan aditif merupakan bentuk penambahan muatan-muatan, tema-tema, dan prespektif-prespektif ke dalam kurikulum tanpa mengubah struktur dasarnya. Artinya pendekatan ini melibatkan upaya memasukkan literatur oleh dan tentang masyarakat dari berbagai kebudayaan ke dalam mainstream kurikulum. Misalnya,

16 James A. Banks, an Introduction to Multicultural Education (Boston: Allyn and Bacon), 26.

Tarbiyatuna: Jurnal Pendidikan Islam; Volume 11, Nomor 2, Agustus 2018 | 219 p-ISSN: 2085-6539; e-ISSN: 2242-4579 
memanfaatkan muatan khas multikultural seperti tema-tema tentang ko-eksistensi, pro-eksistensi, saling menghargai, saling memahami sebagai pemerkaya bahan ajar.

3. Pendekatan aksi sosial, yaitu mengkombinasikan pendekatan transformatif dengan berbagai aktifitas untuk melakukan perubahan sosial. Pendekatan in bertujuan untuk memperkaya keterampilan peserta didik daam melakukan aksi sosial seperti resolusi konflik, rekonsiliasi keberagaman, dan perbedaan budaya.

4. Pendekatan transformatif. ${ }^{17}$ Yaitu pendekatan yang menekankan pada aksi sosial dan politik untuk memecahkan masalah secara logis, melampaui konteks kelas tradisional. Dari sini diharapkan muncul perubahan pedagogik yang mengakui bahwa kelas-kelas tradisional lebih menakankan pada pengajaran teks-teks yang sering memaparkan kategori-kategori tradisional dalam wacana dan evaluasi. Oleh karena itu, perlu mengganti model-model lama untu setidaknya merevisi dan menciptakan model-model baru

\section{Tujuan Pendidikan Multikultural di Indonesia}

Pada konteks ini dapat dikatakan, tujuan utama dari pendidikan multikultural adalah untuk menanamkan sikap simpati, respek, apresiasi, dan empati terhadap penganut agama dan budaya yang berbeda. Lebih jauh lagi, penganut agama dan budaya yang berbeda dapat belajar untuk melawan atau setidaknya tidak setuju dengan ketidak-toleranan seperti inkuisisi (pengadilan negara atas sah-tidaknya

17 Geneva Gay, Bridging Multicultural Theory and Practice (1999), 560-563.

220 | Tarbiyatuna: Jurnal Pendidikan Islam; Volume 11, Nomor 2, Agustus 2018 p-ISSN: 2085-6539; e-ISSN: 2242-4579 
teologi atau ideologi), perang agama, diskriminasi, dan hegemoni budaya di tengah kultur monolitik dan uniformitas global.

Beberapa aspek yang menjadi kunci dalam melaksanakan pendidikan multikultural dalam struktur sekolah adalah tidak adanya kebijakan yang menghambat toleransi, termasuk tidak adanya penghinaan terhadap ras, etnis dan jenis kelamin. Juga, harus menumbuhkan kepekaan terhadap perbedaan budaya, di antaranya mencakup pakaian, musik dan makanan kesukaan. Selain itu, juga memberikan kebebasan bagi anak dalam merayakan hari-hari besar umat beragama serta memperkokoh sikap anak agar merasa butuh terlibat dalam pengambilan keputusan secara demokratis.

Dalam konteks yang luas, pendidikan multikultural mencoba membantu menyatukan bangsa secara demokratis, dengan menekankan pada perspektif pluralitas masyarakat di berbagai bangsa, etnik, kelompok budaya yang berbeda. Dengan demikian sekolah dikondisikan untuk mencerminkan praktik dari nilai-nilai demokrasi. Kurikulum menampakkan aneka kelompok budaya yang berbeda dalam masyarakat, bahasa, dan dialek; dimana para pelajar lebih baik berbicara tentang rasa hormat di antara mereka dan menunjung tinggi nilai-nilai kerjasama, dari pada membicarakan persaingan dan prasangka di antara sejumlah pelajar yang berbeda dalam hal ras, etnik, budaya dan kelompok status sosialnya. Pembelajaran berbasis multikultural berusaha memberdayakan siswa untuk mengembangkan rasa hormat kepada orang yang berbeda budaya, memberi kesempatan untuk bekerja bersama dengan orang atau kelompok orang yang berbeda etnis atau rasnya secara langsung. 
Pendidikan multikultural juga membantu siswa untuk mengakui ketepatan dari pandangan-pandangan budaya yang beragam, membantu siswa dalam mengembangkan kebanggaan terhadap warisan budaya mereka, menyadarkan siswa bahwa konflik nilai sering menjadi penyebab konflik antar kelompok masyarakat. ${ }^{18}$ Pendidikan multikultural diselenggarakan dalam upaya mengembangkan kemampuan siswa dalam memandang kehidupan dari berbagai perspektif budaya yang berbeda dengan budaya yang mereka miliki, dan bersikap positif terhadap perbedaan budaya, ras, dan etnis.Tujuan pendidikan berbasis multikultural dapat diidentifikasi:

1. untuk memfungsikan peranan sekolah dalam memandang keberadaan siswa yang beraneka ragam;

2. untuk membantu siswa dalam membangun perlakuan yang positif terhadap perbedaan kultural, ras, etnik, kelompok keagamaan;

3. memberikan ketahanan siswa dalam mengambil keputusan dan keterampilan sosialnya;

4. untuk membantu peserta didik dalam membangun ketergantungan lintas budaya dan memberi gambaran positif kepada mereka mengenai perbedaan kelompok. ${ }^{19}$

Di samping itu, pembelajaran berbasis multikultural di bangun atas dasar konsep pendidikan untuk kebebasan; yang bertujuan untuk:

1. membantu siswa atau mahasiswa mengembangkan pengetahuan, sikap dan keterampilan untuk berpartisipasi di dalam demokrasi dan kebebasan masyarakat;

18 Zubaidi, Pendidikan Berbasis Masyarakat (Jakarta: Pustaka Pelajar. 2005),128.

${ }_{19}$ Banks, Multicultural Educatian, 1993

222 | Tarbiyatuna: Jurnal Pendidikan Islam; Volume 11, Nomor 2, Agustus 2018 p-ISSN: 2085-6539; e-ISSN: 2242-4579 
2. memajukan kekebasan, kecakapan, keterampilan terhadap lintas batas-batas etnik dan budaya untuk berpartisipasi dalam beberapa kelompok dan budaya orang lain.

Pendidikan multikultural sebagai wacana baru di Indonesia dapat diimplementasikan tidak hanya melalui pendidikan formal namun juga dapat dimplementasikan dalam kehidupan masyarakat maupun dalam keluarga. Dalam pendidikan formal pendidikan multikultural ini dapat diintegrasikan dalam sistem pendidikan melalui kurikulum mulai Pendidikan Usia Dini, SD, SLTP, SMU maupun Perguruan Tinggi. Sebagai wacana baru, Pendidikan Multikultural ini tidak harus dirancang khusus sebagai muatan substansi tersendiri, namun dapat diintegrasikan dalam kurikulum yang sudah ada tentu saja melalui bahan ajar atau model pembelajaran yang paling memungkinkan diterapkannya pendidikan multikultural ini. Di Perguruan Tinggi misalnya, dari segi substansi, pendidikan multikultural ini dapat dinitegrasikan dalam kurikulum yang berperspektif multikultural, misalnya melalui mata kuliah umum seperti Kewarganegaraan, ISBD, Agama dan Bahasa. Demikian juga pada tingkat sekolah Usia Dini dapat diintegrasikan dalam kurikulum pendidikan misalnya dalam outbound program, dan pada tingkat SD, SLTP maupun sekolah menengah pendidikan multikultural ini dapat diintegrasikan dalam bahan ajar seperti PPKn, Agama, Sosiologi dan Antropologi, dan dapat melalui model pembelajaran yang lain seperti melalui kelompok diskusi, kegiatan ekstrakurikuler dan sebagainya. ${ }^{20}$

\footnotetext{
20 Akhmad Sudrajat, Pengertian Pendekatan, Strategi, Metode, Teknik dan Model Pembelajaran (Bandung: Sinar Baru Algensindo, 2008), 4.
} 
Dalam pendidikan non formal wacana ini dapat disosialisasikan melalui pelatihan-pelatihan dengan model pembelajaran yang responsif multikultural dengan mengedepankan penghormatan terhadap perbedaan baik ras suku, maupun agama antar anggota masyarakat.Tak kalah penting, wacana pendidikan multikultural ini dapat diimplementasikan dalam lingkup keluarga. Di mana keluarga sebagai institusi sosial terkecil dalam masyarakat, merupakan media pembelajaran yang paling efektif dalam proses internalisasi dan transformasi nilai, serta sosialisasi terhadap anggota keluarga. Peran orangtua dalam menanamkan nilai-nilai yang lebih responsif multikultural dengan mengedepankan penghormatan dan pengakuan terhadap perbedaan yang ada di sekitar lingkungannya (agama, ras, golongan) terhadap anak atau anggota keluarga yang lain merupakan cara yang paling efektif dan elegan untuk mendukung terciptanya sistem sosial yang lebih berkeadilan.

\section{Kesimpulan}

Berdasarkan uraian di atas, dapat dirumuskan beberapa kesimpulan sebagai berikut:

1. Pendidikan multikultural dirasakan penting untuk menjaga integritas bangsa Indonesia dari perpecahan horizontal sebagaimana terjadi tidak hanya sekali sepanjang Indonesia merdeka. Dengan semboyan Bhinneka Tunggal Ika, pemahaman akan pentingnya perbedaan sebagai sebuah anugerah merupakan titik tolak pendidikan berbasis multikultural; 
2. Ada lima dimensi pendidikan multikultural yang diperkirakan dapat membantu guru dalam mengimplementasikan beberapa program yang mampu merespon terhadap perbedaan pelajar, yaitu: pertama, dimensi integrasi isi/materi (content integration). Kedua, dimensi konstruksi pengetahuan (knowledge construction). Ketiga, dimensi pengurangan prasangka (prejudice ruduction). Keempat, dimensi pendidikan yang sama/adil (equitable paedagogy); dan kelima, dimensi pemberdayaan budaya sekolah dan struktur sosial (empowering school culture and social structure).

3. Tujuan utama dari pendidikan multikultural adalah untuk menanamkan sikap simpati, respek, apresiasi, dan empati terhadap penganut agama dan budaya yang berbeda. Lebih jauh lagi, penganut agama dan budaya yang berbeda dapat belajar untuk melawan atau setidaknya tidak setuju dengan ketidak-toleranan seperti inkuisisi (pengadilan negara atas sah-tidaknya teologi atau ideologi), perang agama, diskriminasi, dan hegemoni budaya di tengah kultur monolitik dan uniformitas global.

4. Pendidikan bukan yang utama, akan tetapi dengan memanfaatkan sektor pendidikan sebagai sarana untuk menanamkan konsep pendidikan berbasis multikultural dirasakan dapat meminimalisir dan menghilangkan pemikiran maupun tindakan arogan karena perbedaan yang berhaluan SARA. 


\section{Referensi}

Asy'ari, Musa. 2004. Pendidikan Multicultural dan Konflik Bangsa, Yogyakarta.

Atmaja, Sapta. Tt. dari buku Multiculturalisme Educations: A Teacher Guide To Linking Context, Process And Content karya Hilda Hernandes

Azra, Azyumardi. 2000. Pendidikan Islam: Tradisi dan Modernisasi Menuju Milenium Baru. Jakarta: Logos Wacana Ilmu.

Banks, J.A. 1993. "Multicultural Educatian: Historical Development, Dimentions and Practrice" In Review of Research in Education, vol. 19, edited by L. DarlingHammond. Washington, D.C: American Educational Research Association. , 1994. An Introduction to Multicultural Education, Needham Heights.

Darmaningtyas, et. al. 2004. Membongkar Ideologi Pendidikan-jelajah UndangUndang Sistem Pendidikan Nasional. Yogyakarta: Resolusi Press.

Depdiknas, Undang-undang RI No. 20 tahun 2003.Tentang Sistem Pendidikan Nasional. pasal 04.

Gay. Geneva, 1999. Bridging Multicultural Theory and Practice.

Gibson, Ivancevich. 1984. Organisasi dan Manajemen Perilaku Struktur Proses. Jakarta: Penerbit Erlangga.

Hanafiah, Nanang dan Cucu Suhana. 2009. Konsep Strategi Pembelajaran. Bandung: Refika Aditama.

Harto, Kasinyo. 2014. Model Pengembanagan Pendidikan Agama Islam Berbasis Multikultural, Jakarta: PT Raja Grafindo Persada.

http://www.ditpertais.net/swara/warta17-01.asp, diakses, 24 Juli 2018

Joyce, Bruce, et. al. 2009. Model of Teaching - edisi kedelapan, diterjemahkan oleh Achmad Fawaizd. Yogyakarta: Pustaka Pelajar.

Karsidi, Ravik. 2008. Sosiologi Pendidikan, Surakarta: LPP UNS dan UNS Press, cet. II.

226 | Tarbiyatuna: Jurnal Pendidikan Islam; Volume 11, Nomor 2, Agustus 2018 p-ISSN: 2085-6539; e-ISSN: 2242-4579 
Kuper, Adam \& Jessica Kuper. 2000. Ensiklopedi Ilmu-Ilmu Sosial. Jakarta: PT Raja Grafindo Persada.

Nieto, S. 1992. Affirming Diversity: The Sociopolitical Context of Multicultural Education. New York: Longman.

Sudrajat. Akhmad. 2008. Pengertian Pendekatan, Strategi, Metode, Teknik dan Model Pembelajaran, Bandung: Sinar Baru Algensindo.

Syafiq, A. Mughni. 1994. Hasan Bandung: Pemikir Islam Radikal, Surabaya: PT Bina Ilmu.

Tilaar, H. A. R. Pedagogik Teoritis untuk Indonesia, Jakarta: Kompas, 2015.

Tim Kreatif LKM UNJ. 2010. Restorasi Pendidikan Indonesia: Menuju Masyarakat Terdidik Berbasis Budaya. Yogyakarta: Ar-ruzz Media.

Undang-Undang Republik Indonesia Nomor 20 Tahun 2003 tentang Sistem Pendidikan Nasional.

Zubaidi, 2005. Pendidikan Berbasis Masyarakat, Jakarta: Pustaka Pelajar. 